\title{
20
}

\section{Building modern enterprises: challenges and requirements}

\section{Mei Wen}

The 14th congress of the Chinese Communist Party was held in October 1992. It was here that Deng Xiaoping officially declared that the aim of China's economic reform was to establish a socialist market system, and since then, China's stateowned enterprises (SOEs) have been reformed. With faster development of markets and the rapid growth of collectives and small private businesses, SOEs were further exposed to market competition in 1992 when dual track prices were merged with market prices.

Different SOEs required different approaches to reform. A variety of contracts were introduced to provide incentives for managers to improve enterprise performance. Some small SOEs were leased to private agents. A number of well-performing SOEs were listed in domestic and international stockmarkets. Many loss-making SOEs experienced liquidation or internal restructuring, and more than 7,000 insolvent SOES went bankrupt. Mergers and acquisition of SOEs were also allowed.

Despite SOEs' poorly-defined property rights of, most Chinese economists did not suggest large-scale privatisation in the earlier economic reform period. Instead, concerns about a possible backlash caused the Chinese government to adopt a piecemeal reform approach and pursue GDP growth.

Recent studies analyse the success of this path to economic reform. For example, (Lau, et al. 2000) and Wen (2002a) claim that keeping major SOEs from privatisation may have helped China evade a decline in industrial output during the earlier period 
of economic reform. Tian (2000) shows that an optimal ownership arrangement is dependent on marketisation. Pure private ownership would not have been welfareoptimal in an economy with very low levels of marketisation. Lau et al. (2000) argue that because China's economic reforms were Pareto-improving, backlash forces were minimised. Yet productivity growth among SOEs indicates that the SOE reforms were at least partially effective (Jefferson, et al. 1999 and Jefferson et al. 1996). And the social safety net function of SOEs has been widely recognised.

Clearly, in almost every facet of its economy, contemporary China is vastly different from the China of the 1980s. While at the beginning of the reform, there were few free markets in major cities for trading agricultural products and small industrial commodities, at the beginning of the 21st century, China not only has networked product markets, but also an imperfect financial market, an imperfect labour market, housing markets, future markets, and even e-commerce. By 1996, less than 10 per cent of commodity categories were under government control. Over 90 per cent of retail prices and 80 per cent of agricultural and producer good prices (as a proportion of output value) were determined by the market.

In addition, major industrial players have changed substantially. At the beginning of economic reform, industrial SOEs contributed over 80 per cent of national industrial output value, with individuals (a type of small private enterprise with fewer than eight employees) and collectives contributed the rest (less than 20 per cent). By 2001 , only 46,767 of the 171,256 of industrial enterprises (with a sales-revenue above 5 million yuan) were either state-owned, or the state had controlling shares in them. These 46,767 enterprises produced 44 per cent of the national industrial output value, contributing 52 per cent to national value added of industry. More than two decades after opening up the economy, foreign and overseas Chinese-funded enterprises (above the designed size) rose from zero in 1978 to 31,423 in 2001, contributing 29 per cent and 25 per cent respectively to gross industrial output value and value added by industry. In addition, there were 31,028 collectives and 5,692 shareholding corporations, which produced 11 and 13 per cent of gross industrial output value, and 9 and 16 per cent of value added of industry.

Since China opened its economy to foreign investors and encouraged the development of private enterprise, firms with different ownership types competed in product markets. This has significantly contributed to China's industrial growth (Wen 2002b). However, there were distortions in the market place. First, changing SOEs from administration units to economic entities did not change their objective to 
pursuing profits, due to poorly-defined property rights and institutional constraints. In fact, because of the lack of a sound social security system, overstaffing in SOEs had been a major obstacle to achieving internal efficiency (Dong et al. 2003 and Wen et al. 2002).

Second, although the increasing power of SOE managers of enabled them to make autonomous decisions based on market information, it also enabled them to strip state assets by pursuing short-run benefits, with SOEs competing more aggressively in the market place than otherwise. This led to a low returns on capital in SOEs and further lowered the accumulation of state assets.

Third, state ownership of major banks meant they were unable to lend to firms according to marginal returns to capital. Loan policies favoured SOEs, which became the major holder of banks' bad loans.

Fourth, to attract foreign investment, tax exemptions and tax reduction policies were given to enterprises with foreign investment and overseas Chinese investment. These preferential policies made taxation for foreign and overseas Chinese invested enterprises much lower than their industrial competitors. ${ }^{1}$

The development of domestic private firms in this distorted market place could be very difficult. Since the late 1990s, increasing international competition, large amounts of state assets stripping, relative poor performance of SOEs, and accumulated bad loans in state banks have led to growing governmental concerns about the maintenance of SOEs and about further reforms in the state sector. Because of the interdependency between the reform of SOEs and that of state banks, and the development of other institutions, the government possibly feels pressured towards further reform, despite the difficulties.

\section{KEY ISSUES IN FURTHER REFORM OF SOES AND STATE BANKS}

Evidence of significant differences in technical efficiency between SOEs and other firms can be seen in the survey data of the third national industrial census (Zhang et al. 2001; Wen et al. 2002). China's competitive industries have problems with internal efficiency, as do industrial market economies and other transitional economies (Wen 2002a). Ownership transformation (zhuanzhior gaizhl) of SOEs in one way or another is desirable to improve the technical efficiency of current SOEs, especially in competitive industries. Although the 'keep the large and let the small go' (Zhuada Fangxiao) policy officially initiated SOE privatisation in China, 
diversification of ownership of SOEs has not yet solved inefficiencies in SOEs and the managing of state assets. There is no unified national account of the sales revenues of small and medium-sized SOEs, and very few comparisons of the different mechanisms used for privatising small and medium-sized SOEs, so it is difficult to estimate the net benefits of 'letting the small go'. Concerns about major state assets and mass unemployment made the government reluctant to change SOE ownership structure substantially.

All Chinese citizens are the nominal owners of state assets, and the various levels of government exercise owners' rights on their behalf. But there are now 1.3 billion Chinese citizens, a very small fraction of the nominal owners can exercise their rights. Because of an imperfect legal enforcement system and tax evasion, central and local governments have been forced to use their own state enterprises for fiscal revenue purposes. Therefore, the vested interests of central and local government officials may have become one of the obstacles to effective diversification of ownership in the reform of large SOES.

Central and local governments are clear about the growth objectives of SOEs. But they are also clear about their low profit-assets ratios and competitive inefficiencies. However, governments have a dilemma because of institutional shortcomings. If SOEs in competitive industries are fully privatised no matter what their size, the government may risk revenue decline if the revenue from selling the SOEs and from increasing taxation is smaller than the revenue from lifetime return to state assets and the costs incurred in social security payments to laid-off workers (ceteris paribus). Meanwhile, maintaining large SOEs in competitive industries in spite of continuing poor performance will certainly result in efficiency losses, and is likely to result in slower development of domestic private enterprises and slower growth of domestic industries.

If the legal enforcement system were effective and there were sound assets markets, after privatising large SOEs in competitive industries, the faster industrial growth and stronger domestic industrial sector would generate more taxation income. This, together with the revenue from selling the SOEs, would create a higher fiscal revenue than keeping these enterprises in government hands. Meanwhile, return to domestic capital would be higher, due to the efficiency gain in industrial enterprises, ceteris paribus.

Establishing an efficient legal enforcement system requires new legislation, which demands political reform and would diminish benefits to government officials. It is 
questionable whether government officials have strong incentives to establish an open and fair auction of those SOEs operating at a loss as opportunities for bribery and corruption would be lost. Illegal personal gains from state asset stripping since the 1990s have resulted in large capital losses. According to Gu (2002) and Zhang (2002), China's annual capital flight increased from US $\$ 10$ billion in 1990 to US $\$ 80$ billion in 2000 . The lack of clearly defined property rights in SOEs means that these SOEs are less attractive as a target for domestic capital in the context of open and competitive industries. The longer-term outcome is that SOEs become undercapitalised, and hence must lean on the government to cover investment shortfalls and financial losses. This places a further burden on the government's fiscal situation and indicates that competitive industry is at the cost of loss of faster growth potential for domestic capital, which will result in loss of long-term fiscal revenue.

Because of these problems, central government has adopted measures to improve the performance of SOEs, including the establishment of a State Asset Supervision and Administration Committee (SASAC), changing performance criteria for the central government-owned SOEs to profits and costs, and strengthening the monitoring of SOEs and the general stress of enterprise governance. According to the 'Temporary Provisions of State Assets Monitoring and Management in Enterprises', State Asset Supervision and Administration Committee can have a say on whether the SOE should undergo further reform towards restructuring, merger, bankruptcy, closing down, changing size or issuing company bonds.

This new system might not solve the problem of high agency costs and it could add new costs for the following reasons. First, normal profits and production costs vary from industry to industry. When one large SOE is reported to have performed so poorly that it should be closed down, arguments about its poor performance could arise, especially in industries where there are only one or two large SOEs. Managers of the SOE could argue their firm may perform better with finance for expansion.

Second, due to a less than accurate accounting system, the risk of loss of employment for managers of poorly-performing SOEs could lead them to expend more effort on manipulating the accounts and lowering product quality. While the regionalism and short sighted-behaviour of some managers of SOEs has caused a lot of redundant investment and excess production capacity in the 1990s, changing the performance criteria of SOEs could result in further short-sighted behaviour by managers. 
Third, like many large SOE managers, SASAC personnel are not the genuine owners of state assets. They are also nominal owners and are appointed by government officials to exercise owners' rights. So there is no guarantee that the SASAC will behave differently from former government officials in charge of large SOEs, especially when final decisions about the fate of a large SOEs is still in the government's hands. If the SASAC were able to help SOEs improve internal efficiency by matching performance with profits and costs, former government offices in charge of large SOEs should be able to do the same.

Fourth, under SASAC monitoring, the selection of managers, one of the most important enterprise governance measures, will not substantially change. It is well known that the selection of most SOEs managers in China was not based on individual business acumen and management capability. If government officials have been reluctant to sack incapable managers because of low profits and high costs, excuses can be found in the large labour force and heavy social burden carried by the SOE.

Fifth, SASAC is already a considerable size, with 20 bureaus as well as the general office. Although former direct government intervention in SOEs apparently became indirect after SASAC was established, increased intervention costs would not necessarily reduce government intervention if these costs were not a concern for government officials. While SASAC might help to collect data on existing state assets, the establishment of SASAC itself will not guarantee an efficiency gain for the state sector. Instead, expectations of SASAC to improve the SOE internal inefficiencies will depend on how SASAC can facilitate diversification of ownership of SOEs, and whether more efficient ownership transformation mechanisms can be adopted for these enterprises.

According to Chen (2003), there are currently about 9,000 SOEs under state government surveillance. The assets of 196 of these are now directly monitored by SASAC. Except for these 196 large SOEs, further reform of the remaining SOEs may involve ownership diversification in one way or another in coming years. Although strong industrial competition, fast development of the non-state sector and high economic growth rates have made issues in the state sector less crucial, many scholars regard reform of SOEs over the past ten years as unsatisfactory. Had the reform of SOEs been more efficient, China's economy may have grown even faster. Institutional shortcomings and the failed efficiency gains to mark the policy of 'keep the large and let the small go'. Accurate evaluation of SOEs assets in is a difficult 
and important issue in ownership diversification. The economic value of these assets always changes with their usage. Potential buyers of assets may know the value to them but may not reveal that value in their bids if the auction is not well designed. ${ }^{2}$ More asset markets should be established with well-designed auction mechanisms.

If the current government objectively reviews the results of 'letting the small go' and learns from past experience, further reform of SOEs may yet move towards more efficiency and fairness. Estimates on the book value of total state assets vary greatly. While Zhao (2003) reports that total state assets was over 11.8 trillion yuan at the end of 2002, Chen (2003) reports total assets of SOEs controlled by the state government at about 17.4 trillion yuan. As the nominal owners of state assets are all Chinese citizens, searching for an optimal reform approach of SOEs and a management approach for state assets should not be limited to approaches of increasing the value of these state assets under government control.

Compared with state government managed assets, further privitisation of SOEs may increase opportunities for more efficient enterprises operation, more even income distribution, and faster growth of domestic capital. This would require more appropriate mechanisms for reforming SOEs in different industries and could be an opportunity to reduce state asset stripping through a fair redistribution of assets and clearer identification of property rights among different interest groups. Yet further ownership diversification of the majority of SOEs (in terms of numbers) need not contradict the fact that keeping some SOEs in non-competitive or crucial industries in the governments' hands would be a sensible strategic tool.

State banks form a large proportion of state assets. In addition to current sole state ownership of the People's Bank of China, now working as China's central reserve bank, and four major commercial banks (Bank of China, Industrial and Commercial Bank, Construction Bank and Agricultural Bank), there are other state banks, and many regional commercial and development banks. In the past, state banks had loan policies favouring SOEs because of ideological discrimination against domestic private entities. Severe industrial competition and high agency costs resulted in the majority of SOEs suffering losses in the 1990s. State banks had to lend funds to many of these SOEs because of the problems associated with mass unemployment and hopes for improving the performance of SOES.

Consequently, state banks accumulated US $\$ 400$ billion in bad assets by 1999 and SOEs were the major holders of NPLs in state banks. In the late 1990s, many foreign banks were allowed to open branches in big cities like Shanghai and Beijing. 
By January 2003, 60 foreign banks were allowed to open branches and to conduct foreign currency businesses without any regional location constraints. Fifty-three foreign banks were approved to open renminbi businesses in nine of the most developed Chinese cities including Shanghai and Shenzhen. Because the loan policies of state banks support the reform of SOEs, soft budget constraints and poor performance resulted in a huge amount of NPLs in state banks. According to Woo (2002), after 170 billion yuan of bad assets were transferred from state banks to the four asset management companies (Huarong, the Great Wall, DongFang, and Xinda) in 1999, the ratio of Non-Performing Loans to total outstanding loans of the four biggest state commercial banks was 0.35 at the beginning of 2002 . This ratio indicates a poor performance of state banks relative to many Western banks, creating concerns for the domestic banking sector with drastic increases in international competition and growing appeal of developing domestic private banks.

The trend for ambitious foreign entries with abundant banking experiences in market economies means that further reform of state banks is both urgent and inevitable for their own survival and for the future of the domestic banking sector. More competition is one way to improve efficiency in the banking sector. As renmimbi businesses have now opened to foreign banks, pending rigorous competition will force state banks into better management structures and lending behaviour to survive. This cannot, however, remove the high principal-agency problem in state banks, or guarantee the fastest increase in the value of the state assets in these banks.

In 2003, foreign investment banks such as Gaosheng and Morgan Stanley were permitted to purchase bad assets from major state commercial banks when the state banks were trying to reduce NPL ratios. Nevertheless, as long as the vicious circle of SOEs and state banks cannot be broken, new NPL will accumulate and state banks will have more bad assets. In fact, rapid changes in market structure in China's banking sector has forced the People's Bank of China to consider exit mechanisms for insolvent banks. Three banking laws ${ }^{3}$ were recently passed. However, if the state banks can move towards ownership diversification (through listing in the stockmarkets within the next few years) and break the ownership link between them and SOES along with the establishment of better governance structure, the efficient reforms of these banks may allow them to gain a first-mover advantage. Recently, domestic private entities and foreign investors have been invited to participate in the ownership diversification of some small and medium-sized regional commercial 
banks. This may significantly increase foreign shares in the banking sector as well as enlarge disparity in income distribution.

In China today, banks incur bad loans due to the lack of effective credit evaluation effective legal enforcement. Although credit evaluation will gradually improve with the increasing collection of information about business and business people, by increasing the number of banks, and having more experienced banks evaluate credit, the system's effectiveness will still be affected by the degree of personal grey and black income in the economy. The forthcoming new provisions in China's constitution for further protection of private property and domestic private businesses could help solve the problem.

Many former SOE workers have been major losers in the reform of SOEs since the 1990s. The hard life of laid-off (Xiagang) and sacked workers has been widely observed (Yin 1998). Lack of social security funds (SSF) and a sound social security system is often regarded as an obstacle to reform. A recent study points out that conditions for maintaining a large proportion of exiting employees in an ex ante SOE often made the buyer ask for discounts on the value of the firm and sometimes even made potential buyers reluctant to purchase the firm. This implies that attaching the labour force to state assets in the sale of SOEs may become an excuse for significant reduction in the value of state assets even though there is no long-term employment guarantee for attached employees.

China is establishing a social security system with economic reform, but current social security is not unified and does not provide the unemployed with enough security. Current unemployment benefits for former SOE employees are from three channels: one third from SOEs, one third from the social insurance system, and one third from the fiscal budget. The unemployment benefit for young unemployed people with little work experience is a minimum payment from the fiscal budget at the poverty line with voluntary work required. Unemployment benefits for young people are available only in some large cities, and not nation wide. ${ }^{4}$ Although there is wide concern about the dramatic increase in the number of laid-off workers from the state sector since 1992, there are few studies focusing on finding the best linkage mechanism for the establishment of a unified social security system with reform of SOES.

This is a topic worthy of many separate studies. Perhaps one approach would be to establish more secondary asset markets and auction state assets openly and 
fairly in the market. Direct transfer to social security funds of part of the revenue from the sales of state assets would be required, plus funds raised from selling state shares of listed SOEs transferred to social security funds, but the employment issue would be separated from ownership transformation in order for the sale of state assets to reach the highest amount. This would raise SSF more rapidly and increase the chance of providing unemployment benefits through a unified social security channel, and different SOEs would have different additional benefits arrangements for their former employees with some regulated cap, depending on the enterprise's financial situation.

\section{INSTITUTIONAL REFORMS FOR FAIRER INCOME AND WEALTH DISTRIBUTION}

The key issues in the further reform of SOEs and state banks are the following

- more efficient operation of existing SOEs and state banks

- sales revenues of state assets

- settlement of sacked workers in a unified social security system

- reduction of opportunity for bribery and state asset stripping

- efficient ownership diversification of some of state banks

- fairer sale of state assets among Chinese citizens for more equal income and wealth distribution both within and across regions.

As the current government has publicly emphasised that it is to serve the Chinese people, and the nominal owner of state assets are all Chinese citizens, an integrated reform package is possible in the coming years. Because SOE and state bank inefficiencies are mainly due to poorly defined property rights and usually accompanied by over-staffing, unemployment may increase in the short term. The development of the non-state sector and fast economic growth will provide more reemployment opportunities. Settlement of former employees of SOEs, state banks, and redundant government officials should be given priority. This would require that part of the revenue raised from further reform of SOEs or state banks ${ }^{5}$ should first be directly transferred to the SSF for covering unemployment benefits.

Only after the required transfer to the SSF had been made could the remaining revenue be kept either by the SASAC for further reinvestment or be partly transferred to the Treasury. Direct transfer to the SSF would help establish a unified social security system, which could provide unemployment benefits to former employees of the state sector, and to unemployed who formerly worked in the non-state sector, 
as well as training programs for re-employment and information services for reemployment. Two important conditions for developing a sound social security system are raising more funds for the SSF and establishing open management of the SSF. ${ }^{6}$ While transparent accounting of the SSF would reduce the risk of mismanagement of the funds, fundraising of the SSF could be closely related to mechanisms used in further reforms. More asset markets and open state asset auctions would clearly help increase revenue from the sale of the assets of SOEs and state banks. These measures would help the government fight corruption reducing discrimination among potential buyers and corruption opportunities through establishing definite objectives for efficient re-allocation of assets.

More small and medium-sized SOEs will be bankrupted, sold directly, or merged (in industries with increasing returns to scale). Ownership diversification of the 196 large SOEs whose assets are currently under the direct administration of the SASAC and ownership diversification of state banks, can proceed in two steps: first, listing those unlisted large SOEs and banks in stockmarkets, and second, reducing state holdings of the shares of these economic entities. As these large enterprises and state banks are major state assets, ownership diversification could provide an excellent opportunity for the government to use market forces to reduce income disparities and improve wealth distribution within and across regions. In many industrial market economies, governments provided equal initial share offerings to their citizens at prices significantly lower than expected market prices, for example, privatisation of the Commonwealth Bank and privatisation of Telstra in Australia. After people begin to trade their shares in the market, an increase in share prices engenders more equal income distribution among citizens. More importantly, this approach fits with prevailing socialist ideology as it provides nominal owners with equal ownership rights of state assets. Citizens become the real owners of large SOEs or state banks and are able to exercise their owners' rights by selling, holding or purchasing shares.

The size of the population would be the basis of objections to this approach. What is stated here is a principle. Actual implementation could be flexible. For example, when we consider diversifying ownership for major state commercial banks, an equal initial share offering of the Bank of China, the Industrial and Commerce Bank, and the Construction Bank could be limited to urban citizens and 49 per cent of total shares (with the state holding the remaining 51 per cent) while an equal initial share offering of the Agricultural Bank could be limited to rural citizens and 70 per cent of 
total shares (with the state holding the remaining 30 per cent). Superficially, this may look like uneven income distribution between urban and rural citizens. But the direct transfer of part of the revenue from the former three banks to the SSF could be made while sales revenue of the Agricultural Bank could be kept by the bank for further investment.

This would bring about appreciation of the shares once they were traded in the market. Together with different initial offering prices of the shares of different banks, it could generate a relatively even income distribution between rural and urban citizens. Interestingly, an asset increase in the Agricultural Bank after partial privatisation could raise more funds for further development of the agricultural sector in the short term. An equal initial share offering of regional state banks could be limited to regional urban and rural citizens. As locations of the 196 large SOEs are geographically uneven, an initial share offering could vary according to the net assets of the enterprises. If net assets are large, the approach used for banks could be adopted. Otherwise, the first-come-first-served principle could be used, with initial offering prices being at a level very close to estimated market prices. It is worth pointing out that while the state could control the speed of ownership diversification through its holding of the shares, this approach does not exclude foreign ownership of state-controlling banks or enterprises. Foreign purchases of shares of these enterprises and banks could be allowed after market trading commences but some different aggregate caps on foreign ownership could be set for different banks and each of the 196 different enterprises. Currently, there are calls for renminbi appreciation. The timing of ownership diversification of state banks and SOEs, the speed of their ownership diversification, and the timing of renminbi appreciation all have strong implications for future domestic wealth.

Like the management of the SSF, open or semi-open management of SASAC would be the most efficient way to battle corruption and state asset stripping. SASAC could hold central records on sales of state assets for each of the major state banks and each of the 196 enterprises, with all details of sales revenues and transfers. These records would facilitate state monitoring and surveillance. Meanwhile, the SASAC should provide public monthly reports on aggregate sales revenue of state assets and major sales. In addition, a public monitoring and reporting system of further reforms could be created so that people would be encouraged to observe monthly reports and reforms closely. With open management of SSF, and open 
accounting of SASAC, together with strong regulation of both SSF and SASAC, public monitoring and enhanced legal enforcement would better protect state assets and would significantly reduce the chances for corruption.

Effectiveness of further reforms of SOEs and state banks will be interdependent as SOEs budgets cannot be hardened with state ownership of major banks. Poor performance of SOEs has been generating huge NPLs for state banks. In further reforms, especially in the ownership diversification of state banks and large SOEs through stockmarkets, government restraint from intervention in the business decisions of these economic entities is important for their ex post efficiency. The establishment of SASAC and semi-open accounting of SASAC would increase the cost of government intervention. The board of directors should be selected according to the 'one share one vote' principle and selection of CEOs should be left to the board of directors for these enterprises and banks to establish a good governance structure. With gradual reduction in state holding shares, more directors will be the genuine owners of the ex post corporations and they will have a stronger incentive to choose CEOs according to their management capability and entrepreneurship.

Development of assets markets is a preliminary condition for the sale of state assets. The sale of state assets, either in whole or in part, can involve different selling mechanisms. The most popular mechanism when the value of a selling item is uncertain is by auction. Auction, a frequently used sale mechanism for achieving high revenue, can achieve efficiency in the allocation of final goods in many circumstances (Dasgupta and Maskin 2000). However, the auction of production capacity in transitional economies has many features that are not considered in the conventional auction literature, which make many usual auction mechanisms inefficient (Wen forthcoming). In transitional economies, either more complicated auction mechanisms need to be designed for achieving efficiency in the presence of an externality, or institutional constraints should be removed for existing auction mechanisms to function effectively. The efficient sale of state assets in China is not a simple issue even theoretically. Expert opinions should be sought in the auction of state assets.

One feasible way would be to employ an expert team (5-10 experts) to choose and design auction mechanisms. The tasks of the expert team would be to review all the major cases of state assets, study appropriate mechanisms, and supervise actual auctions and ownership diversifications. This would not be directly involved in the 
operation of any actual sale. This team could work closely with the SASAC and People's Bank of China in further reforms of SOEs and state banks. Although some funds would be needed to pay their salaries, the efficient auction of the assets of one large SOE or one major state bank would generate enough benefits to justify this. ${ }^{\text {? }}$

The regularity of stockmarkets and their normal operation with less government intervention are important in the whole process. Since the Shenzhen Stock Exchange and Shanghai Stock Exchange were established in 1992, a decade of development of the stockmarket together with legislation of Corporation Lawin 1993 and legislation of Security Law in 1998 have enabled more Chinese enterprises to gain finance through markets. In October 20021,215 corporations listed in domestic stockmarkets and issued $A$ or $B$ shares, and 69 corporations were also listed in foreign stockmarkets, mainly the NYSE. The China Securities Regulatory Commission (CSRC) has been accumulating legislative experience in administration and supervision of company listings, shares issuing, market transactions, for the institutions establishment, funds flowing into the market and future markets.

China's security market is still far from perfect. Unfortunately, because the CSRC is affiliated with the government, it is not able to make impartial judgments. A regulation committee like the CSRC should not be associated with any of the players in the market-that is, it should be independent. But its affiliation with a major market player, the government, means that it cannot fulfil this requirement. China's stock market may gradually improve with further reforms of the state sector and more consistent regulation of the market. Development of the legal enforcement system is crucial if a benign circle between the further development of China's security market and further reform of SOEs and state banks is to be set up.

Opening up China's economy has provided foreigners with opportunities to participate actively in China's economic development. It has also brought China many chances to learn from market economies about advanced technologies and institutions. Since the early 1990s, China has paid great attention to developing its legal system and has legislated a large number of economic and institutional laws. Economic laws in China are similar to economic laws in advanced market economies. However, when an investor gets into trouble in China and has to endure lawsuits, dissatisfaction may arise with legal enforcement, especially for ordinary Chinese, who have little social power or international influence. Lack of rule-of-law is the main reason for corruption. While strengthening legal enforcement is essential for efficiency gains in further reform of the state sector, reforms should also provide opportunities 
to reduce corruption and hence remove some obstacles to the development of legal enforcement.

Vested interest groups (especially government officials) must be treated appropriately. Together with strengthening legal enforcement and reducing opportunities for corruption, an increase in the salary of public servants is necessary, along with gradual changes in local and state government functions in this process of further reforms of SOEs and state banks.

\section{CONCLUDING REMARKS}

China's accession to the WTO and the rapid increase in international competition in its secondary and tertiary industries have made the further reforms of SOEs and state banks crucial and urgent. The effectiveness of further reform of the SOEs and further reform of state banks is interdependent. Appropriate ownership transformation is the most important issue. Efficiency of these reforms requires many other institutional developments, including that of asset markets, a sound social security system, an insurance industry and other service intermediaries, further development of a security market, and reinforcement of legal enforcement. These institutional developments are just part of the whole process of improving China's market, which will further promote economic growth through gains in efficiency and from a more competitive allocation of resources.

As China's income disparity is of great concern, partial privatisation of large SOEs and state banks with a more even income distribution is both socially desirable and ideologically justifiable. While further reforms and institutional developments provide the government with an opportunity to reduce corruption significantly, efficient reforms and institutional development can be part of the fight against illegal economic conduct. If China can be successful in these state-sector reforms and institutional development it will attract more investments because of its rapid increase in per capita GDP, but also by significant improvements in living standards.

\section{NOTES}

1 For example, in 2001, the ratio of the sum of sales tax and extra changes and value added tax to total profit of SOEs and enterprises with the state having controlling shares was about 2.24 times that of foreign funded enterprises, and 2.11 times that of overseas Chinese (from Hong Kong, Taiwan and Macau) funded enterprises. The ratio of value added tax of SOEs and enterprises with the state having controlling shares was about 1.71 times of foreign funded enterprises, and 
1.58 times of overseas Chinese (from Hong Kong, Taiwan and Macau) funded enterprises. The laxation rate of domestic collectives was somewhere between that of the state sector and foreignfunded sector.

2 See Tan (2002) for a survey on Auction Theory and Wen (forthcoming) for comparisons among different SOE reform approaches in an industrial study.

3 They are Revision of the Law of People's Bank of China, Revision of the Law of Commercial Banks and Supervision and Administration Law of Banking Sector.

4 See www.moiss.gov.cn for details of the development of China's social security system.

5 Such as revenue of the assets sale of insolvent SOEs, part of revenue raised from selling small and medium SOEs, and part of the funds raised from ownership diversification of state banks and large SOEs through stock market

6 Development of a sound social security system, development of insurance industry and fast development of the non-state sector can significantly remove worries about further unemployment in further reforms of SOEs and state banks.

7 In a survey conducted by SETC and IFC in 2002, among the 311 firms experienced ownership transformation (gaizhi) in one way or another, auction mechanism is used only for 27 firms.

\section{REFERENCES}

Chen, L, 2003. Perfecting the Counter-Corruption Mechanism in the Administration and Supervision of State Assets', Chinanew.com. Available online at www. Chinanew.com [Accessed 4 August 2003].

Dasgupta, P. and Maskin, E.S., 2000. 'Efficient auctions', Quarterly Journal of Economics, 115(2):341-88.

Dong, $X$. and L. Putterman, L., 2003. 'Soft budget constraint, social burdens, and labor redundancy in China's state industry", Journal of Comparative Economics, $31(1): 110-33$.

Garnaut, R. and Song, L., 2002. China 2002: WTO accession and world recession, Asia Pacific Press, Canberra.

Gu, L., 2002. 'Capital flight-China's hidden financial catastrophe', Guoji Shangwu, 7 [in Chinese].

Jefferson, G.H., Singh, I., Xing, J. and Zhang, S., 1999. 'China's industrial performance: a review of recent findings', in G.H. Jefferson and I. Singh (eds), Enterprise Reform in China: ownership, transition, and performance, Oxford University Press, Oxford:127-52. 
Jefferson, G.H., Rawski, T. and Zheng, Y., 1996. 'Chinese industrial productivity: trends, measurement issues and recent developments', Journal of Comparative Economics, 23(2):146-80.

Lau, L.J., Qian, Y. and Roland, G., 2000. 'Reform without losers: an interpretation of China's dual track approach to transition', Journal of Political Economy, 108(1):120-43.

Qian, Y. and Wu, J., 2002. China transition to a market economy: how far across the river, Working Paper of Department of Economics, University of Maryland, College Park.

Tan, G., 2002. 'Auction theory', in G. Tian (ed.), Frontier Development of Modern Economics and Finance, Shangwu Press, Beijing:267-330.

Tian, G., 2000. 'Property Rights and the Nature of Chinese Collective Enterprises', Journal of Comparative Economics, 28(2):247-68.

Wen, M. (forthcoming), 'Bankruptcy, sale, and mergers as a route to the reform of Chinese SOEs', China Economic Review, n.a.

Development of Modern Economics and Finance, Shangwu Press. Beijing:564609.

- 2002b. 'Competition, ownership diversification and industrial growth of China', in R. Garnaut and L. Song (ed.), China 2002: WTO accession and world recession, Asia Pacific Press, Canberra:63-80.

- Li, D. and Lloyd, P., 2002.'Ownership and technical efficiency-a cross-section study on the third industrial census of China', Economic Development and Cultural Changes, 50(3):709-34.

Woo, W.T., 2002. 'Some unorthodox thoughts on China's unorthodox financial sector', China Economic Review, 13(4):388-93.

Yin, X., 1998. 'The macroeconomic effects of waiting workers in the Chinese economy', Journal of Comparative Economics, 26(1):150-64.

Zhang, A., Zhang, Y. and Zhao, R. 2001. 'Impact of ownership and competition on the productivity of Chinese enterprises', Journal of Comparative Economics, 29(2):327-46.

Zhang, X., 2002. 'Analysis of capital flight from China', Journal of Beijing Polytechnic University (Social Sciences Edition), 2(3):47-51.

Zhao, B., 2003. 'Total state assets now over 11 trillion yuan', Jingii Chankao Bao, 5 June.

Zhou, Xiaochuan, 2002. Organisation Structure of China's Capital Market, Beijing. 